全くなかったものが数種見つかるなど実用化可能な酵素 が多数見いだされた。そこで生産量が多く実用化が期待 された Rsa I の isoschizomer であるAfaI をA.facilis $28 \mathrm{H}$ 株上り均一に精製し，蛋白質化学的，醇素化学的 諸性質の検討を行っだ．以後これまでた $16 \mathrm{R}, 22 \mathrm{M}$,

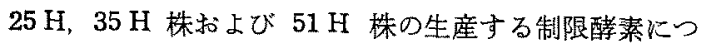
いてもそれぞれ精製し，切断部位等の諸性質を明らかに した (4〜7)、また最近, 著者らは, 酸性環境より単離した 好酸性細菌の新属 新種 Acidobacterium capsulatum 中に最適 $\mathrm{pH}$ が酸性側にある二ニークな耐酸性の $\beta$-グ ルコシダーゼを見いだし，均一に精製すると共に糖䎐移 反応を含む諸性質を明らかにしだ'．以上の研究に上り 好酸性細菌が醉素源としても極好有望であることが明 らかとなっだ(9).

今後, 好酸性細菌の宿主・ベクター系を完成させると 共に好酸性細菌の新たな利用法を開発していきたい，

最後に，本研究に対してご援助賜りましな農芸化学研 究奖励会に深く感謝いたします。

（1）稲垣賢二，友野 潤，岸本憲明，杉尾 剛，田野 達男, 田中英彦: 平成 3 年度日本酸醉工学会大会 满演要旨集, p.129 (1991).
（2）稲垣賢二，友野 潤，杉尾 剛，田野迲男，田 中英彦：日本農芸化学会誌（1992年度大会誨 演要旨集)，66，542 (1992).

(3) D. Dou, K. Inagaki, K. Kita, A. Ohshima, N. Hiraoka, N. Kishimoto, T. Sugio. and T. Tano: Biochim. Biophys. Acta, 1009, 83-86 (1989).

(4) K. Inagaki, D. Dou, K. Kita, N. Hiraoka, N. Kishimoto, T. Sugio, and T. Tano: J. Ferment. Bioeng, 69, 60-62 (1990).

(5) K. Inagaki, F. Kobayashi, D. Dou, Y. Nomura, H. Kotani, N. Kishimoto, T. Sugio, and T. Tano: Nucl. Acids Res., 18, 6155 (1990).

(6) K. Inagaki, T. Ito, H. Sagawa, H. Kotani, N. Kishimoto, T. Sugio, T. Tano, and H. Tanaka : Nucl. Acids Res., 19, 6335 (1991).

(7) H. Sagawa, H. Kotani, Y. Nomura, K. Inagaki, T. Tano, N. Kishimoto, M. Takagi, and K. Nakajima: Nucl. Acids Res, 20 , 365 (1992).

(8) N. Kishimoto, K. Inagaki, T. Sugio, and T. Tano: J. Ferment. Bioeng., 71, 318-321 (1991).

（9）稻垣賢二：酸醉工学会誌，69，401 (1991).

\section{大腸菌のメタボリック・エンジニアリングとバィ オマスからのエタノール生産}

宮崎大学農学部生物資源利用学科 太田一良

植物系バイオマス，特に食糧と競合しない未利用セル ロース資源を有效に利用して然料用エタノ一ルを生産す るためには，その構成糖である 5 炭糖と6 炭糖を効率上 くエタノールに变換する発醉菌の使用が必要である.し かし，従来のエタノ一ル発醉菌である Saccharomyces 醉母とZymomonas 細菌は 6 炭糖のみしか利用でさな い, 一方，大腸菌など腸内細菌は，嫌気的条件下で植物 系ハイイオマスに由来するすべての 5 炭糖と6 炭桾を代謝 することが可能であるが，乳酸，酢酸，キ酸，コハク酸， エタノール, $\mathrm{H}_{2}, \mathrm{CO}_{2}$ を生成する (混合酸型発酵).

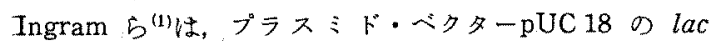
ブロモーターの下流に Zymomonas mobilis のエタノー ル生成経路をコードするピルビン酸脱炭酸醉素遗伝子 $p d c$ とアルコール脱水素酵素遺伝子 $a d h B$ を䌘いて人 工的な pet (production of ethanol) ホペロンを構築し た.この petオペロンを大腸菌に導入した結果，ピルビ ン酸からの代謝の流れが大腸菌本来の混合酸型発醇から エタノール発醉へ転換した. 本研究では, pet オペロン
による大晹菌など腸内細菌のメタボリック・エンシニア リングと植物系バイオマスからの文ノ一ル生産への応 用について検討し，以下の成果を得な。

\section{1. 組換え大腸菌によるエタノール発酵(2-5)}

pet オペ唼名つ多コピーの組换えプラスミド pLOI 297 を導入した Escherichia coli B 株に上るェ夕 ノール発酵試験を種々の条件で行った．植物系バイオマ スの主要 5 孷糖であるキシロース $(8 \%)$ から (理覦收量の $96 \%$ ) のエタノールが生成した. キシロー スに加点て，同しく構成糖であるグルコース，マンノー ス, アラビノース，ガラクトースも效率よくエタノール に変換した.

\section{2. pet オペロンの大腸菌染色体への組込み(6)}

pet オペロンの下流にクロラムフェニュール耐性遺伝 子 cat を付加した断片をプラスミド $\mathrm{pHB} 4$ 上のピルビ ン酸・ギ酸リアーゼ遗伝子 $p f l$ 内部の $\mathrm{Bam} \mathrm{HI}$ 部位に 挿入し，プラスミド pLOI 510 を作成した。この pLOI 510 から複製開始点 ori 除去した断片家環状化し，E. coli B 株飞導入した，その結果，染色体上の $p f l$ 領域と の相同的組換えにより petオペロンを染色体に組迄んだ KO3 を得た. KO3 では, E. coli B (pLOI 297) 株に 比べて組込变れた petオペロンの安定性は増大したが， 
コピー数が少ないためエタノール生成量は微弱であっ

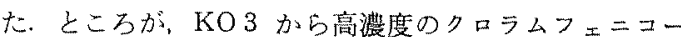
几 $(600 \mu \mathrm{g} / \mathrm{ml})$ に酎性定示自然突然変異体として取得 した KO4 では同時に pet オパロンの発現量が E. col B（pLOI 297）株に匹敵するレベルにすで增大した。 さ らに，KO4のコハク酸生成䋊路を不活性化させるため frd 变異を導入した KOIIを作成した，酸生成量が少 ないKO11 は培医菌体濃度が E. coli B 野生株に比心゙ て高いので，異種タンパ質生産の宿士としても利用で

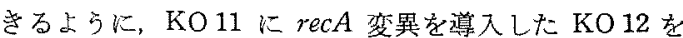
搆築した。こような染色体組这型の組換之大晹菌 は，10\% グルコースと $8 \%$ キシロースからそ秃ぞれ $54.4 \mathrm{~g} / l$ と $41.6 \mathrm{~g} / l$ のエタノール索生成した。

3. pet オペロンによる腸内細菌 Klebsiella oxytoca M 5 A 1 株のメタボリック・エンジニアリング(7)

E. coli B 野生株の内在性プラスミドを pet オペロンの ベクターとする組換えプラスミド pLOI 555 を構築し た. pLOI 555 を導入した K.oxytoca M 5 A 1 株は，10 \%キシ口ース执よびグルコースから48 時間でそれぞれ $46 \mathrm{~g} / l$ と $48 \mathrm{~g} / l$ のエタノールを生成した，特にキシロー スからのエタノールの Volumetric Productivityは上述 の組換え大晹菌に比べ約 2 倍の $2.0 \mathrm{~g} / / \mathrm{hr}$ に上昇した。
本研究の遂行にあたり，終始ご指導賜りました米国フ ロリダ大学微生物学科 L. O. Ingram 教授に心加ら御礼 申し上げます。また，本研究に対してご援助くださいす した財団法人農芸化学研究䍃励会に深謝いたします。

(1) L.O. Ingram, T.Conway, D.P.Clark, G. W. Sewell, and J.F.Preston : Appl. Environ. Microbiol., 53, 2420-2425 (1987).

(2) K. Ohta, F. Alterthum, and L. O. Ingram : Appl. Environ. Microbial., 56, 463-465 (1990).

(3) L.O. Ingram, F. Alterthum, K. Ohta, and D. S. Beall : Dev. Ind. Microbiol., 31, 21 30 (1990).

(4) L. O. Ingram, K. Ohta, and D.S. Beall, in "Energy from Biomass and Wastes XIV", ed. by D. L. Klass, Institute of Gas Technology, Chicago, Ill., 1991, pp. 1105-1125.

(5) D. S. Beall, K. Ohta, and L. O. Ingram: Biotechnol. Bioeng., 38, 296-303 (1991).

(6) K. Ohta, D. S. Beall, J. P. Mejia, K. T. Shanmugam, and L. O. Ingram: $A p p l$. Environ. Microbiol., 57, 893-900 (1991).

(7) K. Ohta, D. S. Beall, J. P. Mejia, K. T. Shanmugam, and L. O. Ingram : Appl. Environ. Microbiol., 57, 2810-2815 (1991).

\section{ヒト・リポ蛋白質リパーセ（LPL）のin vitro， 動物細胞, 酵母での発現}

国立循環器病センター研究所 高木敦子, 池田康行

【目的】脂肪，特に非極性脂質は，水に汪々んど溶り ないので，生体内での輸送のため沉蛋白質とりン脂質汇 覆われた形として存在し，血中を移動する．この複合体 を血獎りポ蛋白といら，LPLは：上トをはじめ高等動物 の血漿りポ蛋白のトリダリセりド異化代謝记関与する䌅 蛋白質酵素である，脂肪組織や心筋などの実質細胞で合 成・分泌され，血管内皮細胞表面の一パラン硫酸样糖鎖 に結合し，血中のリポ蛋白水解を行う，本醉素の欠損に より，血中カイロミクロンが增加するI型高脂血症が引 き起こされ゙!，重篤な場合は死に至る。この上5K LPL はリポ蛋白代謝において非常に重要な役割を果たす。 LPL の in vitro，動物細胞叔よび酵母での発現を調べ， 今後 LPL を高脂血症改善剂として用いるなぬの情報を 得ることを目的とする.

【材料と方法】ヒト LPL の精製とその抗体の作成： LPL はヒト，ポストへパリン血漿 (PHP) が精製 乙(2)，ウサギに免疫して特異的抗七下 LPL ポリクロー
ナル抗体を得た(2)、細胞の標識と標識された LPL の解 析：細胞を ${ }^{35} \mathrm{~S}$ メチオニンでパス標識し，特異的七ト LPL 抗体で標識 LPL を沈降させ SDS-PAGE で解析し た. ヒト LPL CDNA のクローニング：LPL を合成し ていると知られている THPI 細胞から cDNA ライブラ リーを作成し，ヒト脂肪組織の LPL cDNA の一部をプ ローブとしてクローン化した，in vitro 転写・翻訳系： pBluescript SK II M13 ( ) (Stratagene 社) K, LPL cDNA をサブクローンし，in vitro 飞て転写を行わせ， ウサギ網状赤血球ライセートを用いて in vitro で翻訳 を行った．動物細胞（Cos 1) での発現：pEUK-C ベク ター（Clontech 社）につないだ LPL 遺伝子の導入活 高井ら ${ }^{(3)}$ の方法によった，醉母 (Schizosaccharomyces: pombe) での発現：醉母発現ベクター $\mathrm{pcL}^{4)}$ と宿主は 東京大学・医学部岡山博人教授により供与された．形質 転換は酶酸りチウム法によって行った。

【結果と考察】(1)LPL cDNA のクローニング：TH PI からヒト LPL cDNAをクローン化し，その塩基配 列はとト脂肪組織と胎盤からのそれと同じであっだ゙ (2)THPI K括引るLPL の合成：THPIを用いての LPL. 蛋白の生合成実験の結果を図1に示した，分子量 61 